\title{
PROFESSIONAL VALUES, ETHICS, AND PROFESSIONALISM OF PUBLIC RELATIONS PRACTITIONERS
}

\author{
SYED ARABI IDID \\ INTERNATIONAL ISLAMIC UNIVERSITY MALAYSIA \\ MOHAMMED FADEL ARANDAS \\ THE NATIONAL UNIVERSITY OF MALAYSIA
}

\begin{abstract}
This study explores the influence of education, length of service, professionalism, and ethics on the professional values of public relations practitioners in Malaysia. A total of 427 questionnaires were distributed to public relations practitioners in Malaysia, and 322 questionnaires were returned. The study included $61 \%$ female respondents, and $39 \%$ male respondents. The study analyzed and identified the influence of professionalism and ethics on professional values of public relations practitioners. Additionally, the study examined whether education and experience influence professional values through professionalism, and code of ethics. Six hypotheses were tested to answer the research questions. The results from this study fully supported the hypotheses indicating that professionalism and ethics had an influence on professional values of public relations practitioners. The results also showed that
\end{abstract}


education influenced both professionalism and ethics, and length of service influenced both professionalism and ethical practice.

Keywords: Professional values, public relations, practitioners, professionalism, code of ethics.

\title{
NILAI-NILAI PROFESIONAL, ETIKA DAN PROFESIONALISMA DALAM PENGAMAL PERHUBUNGAN AWAM
}

\begin{abstract}
Abstrak
Kajian ini meninjau pengaruh pendidikan, tempoh perkhidmatan, profesionalisma dan nilai-nilai etika profesional pengamal perhubungan awam di Malaysia. Sebanyak 427 soalselidik telah diedarkan kepada pengamal perhubungan awam di Malaysia, dan 322 soalselidik telah dikembalikan. Kajian ini melibatkan $61 \%$ responden wanita, dan 39\% responden lelaki. Kajian ini menganalisa dan mengenalpasti pengaruh profesionalisma dan nilai-nilai etika profesional pengamal perhubungan awam. Selain itu, pengkaji ingin melihat sama ada pendidikan dan pengalaman mempengaruhi nilai-nilai profesional melalui profesionalisme, dan kod etika. Enam hipotesis telah diuji untuk menjawab persoalan kajian. Hasil kajian ini menyokong sepenuhnya hipotesis bahawa profesionalisma dan etika mempunyai pengaruh ke atas nilai-nilai profesional pengamal perhubungan awam. Keputusan juga menunjukkan bahawa pendidikan mempengaruhi kedua-dua profesionalisme dan etika, begitu juga tempoh perkhidmatan yang mempengaruhi kedua-dua profesionalisme dan amalan beretika.
\end{abstract}

Kata kunci: Nilai-nilai profesional; perhubungan awam; pengamal; profesionalisma; kod etika 


\section{INTRODUCTION}

Professional values have always been considered as integral to the profession. Values shape the direction of the profession, and in many ways members of the general public evaluate the profession if the practitioners adhere strongly to the values that they cherish. Part of the value system enshrined will be the code of ethics that shape the ethical practice of the practitioners. The current study is undertaken to explore the factors influencing professional values of public relations practitioners. Kruckeberg (1998) said that public relations, as a profession or occupation, has its own set of professional values, curricular needs, beliefs, and theories of both humankind and society. Professional values aimed to encourage discipline, excellence and service ethics in the "new professions".

Wong (2011) mentioned that professional values play an integral role in maintaining the viability of a profession. This highlights the significance of professional values to a profession. Explaining core professional values allows professionals to convey their societal contributions to the public, and to conceptualize their work. Grunig (2000) stated that professional values in public relations can be considered the centre of ethical decision making. The ethics of public relations include the application of professional and personal values of individuals beside the values of the public and clients or organizations. Nearly all public relations national organizations or associations have their professional code of ethics. Most of these organizations emphasize educating their members about professional standards. They have the right to blame or expel practitioners who violate their professional ethics, or who has been convicted of a crime in a court of law (Wilcox \& Cmeron, 2009). Schank \& Weis (2001) said that the development of professional values occurs through a series of connected practice, beginning during the years of practice and experience of professional education. In the workplace, this development is considered an essential part of professional socialization of practitioners. Practitioners in Malaysia are suggested to have good skills, education or basic knowledge, and experience in the public relations field in order to have a major role in an organization (Ahmad, 2010).

Values are multidimensional. A total of 11 professional values, consistent with the values of the Public Relations Society of America had professionalism as one of them (Boynton, 2006). The Global Alliance for Public Relations and Communication 
Management stated five professional values, of which professionalism is considered as one of them. Professionalism from an Islamic perspective should be based on basic values consisting of faith, excellent character, and strive towards perfection, consciousness, responsibility, excellent performance, and self-accountability (Kasule, 2013).

A test of the professional values among the public relations practitioners is done for a number of reasons. One reason is the difference in cultural values as many past researches on the profession has been undertaken in the United States and in Australia, with few studies being conducted in developing societies. This study is part of the gathering of data on the profile of public relations practitioners in Malaysia and to have an understanding on the growth of the practice in professional values and satisfaction of the practitioners in their work place. The two previous studies managed to get 186 respondents in 1977 and 188 respondents in 1994 (Idid, 1986; 2005). In terms of the number of respondents collected, we were satisfied that a fairly sizeable number was obtained to provide a profile of the practitioners in Malaysia in the current study.

\section{STATEMENT OF THE PROBLEM}

There is a need to analyze professional values, and to explore the factors influencing professional values of public relations practitioners in Malaysia such as education, length of service, professionalism, and code of ethics. The identification of these values gives practitioners an understanding of how and why certain activities take place in organizations while others do not. The findings would enable a comparative understanding of the practice in Malaysia compared to the practice in other countries.

MacCarthaigh (2008) said that the weak application of values or reinforcement of inappropriate values leads to dilemmas of both ethics and decision-making based on values. The identification of these values gives practitioners an understanding of how and why certain activities take place in organizations while others do not.

The commitment to professional values will improve professional practice, thus affecting the reputation of organizations, and reflect a positive image to their stakeholders. Organizations without professional values will have a negative influence on the behavior of practitioners, the reputation of organizations, decision-making, and perception among consumers. Professional values are considered the key to success 
and advancement of any organization. The absence of professional values in public relations adversely affects the practice of public relations as a whole.

\section{SIGNIFICANCE OF THE STUDY}

Some scholars (Grunig, 2000; Grunig, Toth \& Hon, 2000; PRSA, 2000; \& Boynton, 2006) have dealt with the topic of professional values in public relations. Previous studies focused on selected factors influencing professional values such as on education (Al-Enad, 1992; \& Rassin, 2008); on ethics (Winston, 2005; \& Barnard, 2008); on professionalism (Boynton, 2006; \& Panina \& Bierman, 2013); and on service (Synnott, 2001). The present study has included other factors to understand the perception of public relations practitioners regarding professionalism, code of ethics, and professional values.

The present study provides added information by finding out the perception of public relations practitioners regarding professionalism, code of ethics, and professional values. This study will contribute to the growing interest of public relations in Malaysia and other countries as well.

It is important to conduct this research since professional values influences ethical decision making, behaviour of public relations practitioners, reputation of organizations, attitudes and practices of practitioners, and encourages excellence and discipline.

Applying this study in Malaysia will develop both local and global practice and body of knowledge of public relations. Malaysia is also considered one of the most economically developed countries among Muslim societies. It has a multicultural, multi-religious, and multi-ethnic environment. Kaur (2002) said that Malaysia can aspire and lead its Asean neighbors in this world through enacting a character of public relations for better enhancement and recognition of the profession.

\section{RESEARCH OBJECTIVES}

The research objectives will be guided by the following questions:

1. Does education and experience affect the professionalism and code of ethics of public relations practitioners?

2. Does the perception on professionalism and code of ethics affect practitioners' perception on professional values? 


\section{PROFESSIONAL VALUES}

There are numerous definitions of professional values such as defining professional values as standards of work that are acceptable to both professionals and practitioners (Schank \& Weis, 2001) or are aimed at influencing behavior by providing a framework for evaluating attitudes and beliefs or a framework influencing group behaviour (Kubsch, Hansen \& Huyser-eatwell, 2008) or commonly shared values by members of a particular profession (Singhapakdi \& Vitell, 1993). Values are important to the profession as they support the achievements of quality outcome (Schank \& Weis, 2001), or allow planning, evaluation, and execution of specific interference directed to have better integration and transmission in the professional practice.

Specific to public relations, Parsons (2008) defined values in terms of five pillars of ethics as follows: (1) Beneficence or to do well; (2) Confidentiality or to respect privacy; (3) Non-maleficence or to do no harm; (4) Fairness to be fair and socially responsible; and (5) Veracity or to tell the truth. Allen and Davis (1993) stated seven professional values in consultation viz, professional development, freedom of client choice, professional autonomy, positive nature of change, scientific inquiry, adaptability or flexibility, and creativity or innovation.

The researchers would suggest five professional values which are: (1) Trustworthiness and Altruism trustworthiness is an important professional value for professionals who should have loyalty and adherence to forward their organizations. Altruism is devotion and dedication to help and serve others and in related voluntary activities. This is in line with an organization's employees in activities to make them feel part of the organization, and also provide them by safe environments; (2) Accountability having personal accountability will enable practitioners confidence achieve positive outcomes for their organizations. The practitioners, in this case, should be accountable to their organizations, employees, clients, and stakeholders; (3) Impartiality and Credibility practitioners should take into account and maintain impartiality at work. Organizations should ensure impartiality and credibility of their practitioners before and during their employment; (4) Transparency of practitioners can enhance organizational efficiency. Practitioners are also required to facilitate the accessibility, usability, and sharing of all information; and (5) Integrity and honesty 
because practitioners with integrity will satisfy all stakeholders and, in turn, will positively reflect their performance.

\section{PROFESSION}

Understanding the nature of a profession is a pre-requisite to an understanding of the professional values, given the abstract nature that is associated with the term. Freidson (1994) said that the concept of profession was largely taken and assumed for granted, and there was little systematic thinking about it until an academic sociology in the United States expanded its meaning through various empirical studies. The word "profession" is taken to mean an occupation that is organized by a special set of institutions sustained in part by a particular ideology of expertise and service although the word connotes more than just a career.

Evetts (2003) considered profession as a general group of occupations based on both tacit and technical knowledge that the occupants are said to possess. Professions are also basically a knowledge-based category of occupations following a period of vocational training, tertiary education, and experience.

The researchers have defined profession as one kind of occupation, which has high standards and special requirements. It is based on a special body of knowledge, values, accreditation from professional bodies, licensing and certification, experience, special training, obligation to code of ethics, commitment to social responsibility, and serving the society. A profession should be respected from society more than other occupations because of its added special requirements.

The characteristics and standards of professions are numerous. Sha (2011) declared that among the characteristics of a profession in public relations include: standardized education based on a theoretical body of knowledge, subscribing to codes of ethics, belonging to professional associations, be recognized and acknowledged by the public through accountability, certification or accreditation.

Occupations are regarded to have developed over time to take the status of a profession.Turk (2006) argued that an occupation can become a profession only with certain conditions: (1) having a substantial body of research-based knowledge; (2) benefiting from a standardized education systems that create and disseminate knowledge; (3) an obligation to lifelong professional learning; (4) core ethical 
principles; and (5) fundamental to the concept is the sense of responsibility to improve the civil societies.

Wylie (1994) expressed four basic requirements for a profession: (1) examination and certification by the state; (2) a well defined body of scholarly knowledge; (3) completion of general standardized and prescribed course of graduate study; and (4) Oversight by the state agency which has disciplinary powers over practitioners' behavior.

\section{PUBLIC RELATIONS IN MALAYSIA}

The professional values and other factors have developed over a period of time and made their influence on the practice of public relations in Malaysia. The development of public relations predates the achievement of independence in 1957, the practice being strongly influenced by the growth of British public relations. The establishment of the Department of Public Relations in Malaysia was in accordance with the decision of the Colonial Office in London for colonies to have Departments of Public Relations. The Department of Public Relations was founded when the Malayan Union was established in 1946.

The role of public relations in Malaysia is deemed a positive role in enhancing development in the country in both the government and private sectors (Ahmad, 2010; and Idid, 1992). The change of both political and economical situation in Malaysia has brought an influence on the development and practice of public relations.

Taylor \& Kent (1999) stated that the case of public relations in Malaysia was similar to many other nations. Malaysia is moving towards more privatized services from government-owned public services. Public relations are often more influenced in Asia by hierarchic relationships and Eastern theology. Freitag \& Stokes (2009) mentioned that there were some similarities in the history of public relations in Malaysia and Singapore. In both countries, public relations faces challenges of moving from a profession controlled by government campaigns aimed to support the process of nation-building to profession with a strong presence of private-sector.

Idid (1998) said that the value of public relations and information activities are fully recognized by the public sector as a strategy to win both the minds and hearts of the people. The adoption of public relations in the private sector falls slightly behind the public sector. The development of public relations in Malaysia appears to expand 
from the public sector to the private sector. Kaur (2002) stated that there had been a growing significance in public relations as a profession in Malaysia, although only slightly in comparison with rapid economical growing in the country. There is also an increase in the importance of the management function of public relations. Recently, practitioners of public relations are calling to legitimatize the profession. Several sectors in Malaysia are beginning to recognize the need of the professional practice in public relations management.

Kaur \& Shaari (2006) mentioned that public relations in Malaysia have its roots in governmental sectors as a formally recognized practice. However, in the past two decades, public relations have seen growth and development, especially since privatization. The expansion of public relations studies in Malaysia also supports its practitioners by developing required skills and knowledge. Practitioners will be able to deliver an effective performance in several managerial tasks and that will contribute to its growing professionalism. In public relations, the notion of professionalism is not properly defined. Abdullah \& Threadgold (2008) mentioned that it is important to view the nature and requirement of professionalism to seek the integration of professional and educational standards of public relations. The accreditation is considered a very important requirement for the professionalization of public relations practice. IPRM (2012) stated that the level of professionalism in public relations practice in Malaysia has increased through the accreditation programme. The accreditation programme considers a measure of experience and competence in public relations practitioners.

Abdullah \& Threadgold (2008) stated that the adherence to code of ethics is very significant to public relations professionals. Although there exists code of ethics in the Constitution of the Institute of Public Relations Malaysia, the code of ethics for IPRM is not mandatory to the practitioners. Practitioners can use the Code as a guide to their practice and behavior or disregard it altogether/ to members of IPRM, the code of ethics is one that they have to abide. Generally, in public relations, its practitioners take their guidelines from social, religious, and cultural norms along with instructions on business the government. Morality becomes the guide for the practitioners in their professional conduct (Kaur \& Shaari, 2006).

Idid (2005) mentioned that the establishment of IPRM in 1962 was to advance public relations interests in Malaysia. IPRM as a professional body plays a supportive 
role in ensuring a greater level of professionalism in its practitioners through the Code of Professional Conduct, Code of Ethics, and official training for its members. Both the struggle for charter status and accreditation demonstrate accountability and professionalism on practitioners' part and confirm the role of IPRM in providing guidance, setting the benchmark, and training for the industry of public relations in Malaysia. From the very beginning, IPRM stressed on the notion that practical, academic and formal training are essential to strengthen its practice in Malaysia.

Kaur (2002) stated that IPRM had been seeking to formalize professional status of its practitioners through legislation. There was an attempt by IPRM to achieve a Charter status for public relations in Malaysia. Taylor \& Kent (1999) said IPRM is an active body. It has regular meetings, publishes monthly newsletter (Berita), and organizes guest lectures. IPRM also has an active role in the development of public relations studies at college and university levels.

Abdullah \& Threadgold (2008) stated that in Malaysia the belief that obtaining an academic qualification in public relations is more important than obtaining only experience for its practitioners. Although the public relations industry has grown due to the influential influence of Western knowledge in public relations, it has not achieved a professional status in society as a whole. Idid (1998) mentioned that public relations in Malaysia are taught at both undergraduate and graduate levels in local universities, and is perceived as a popular course by undergraduate students. Ahmad (2010) stated that currently, there are several local universities in Malaysia such as USM, UM, UUM, UPM, and IIUM that are offering public relations programmes and courses. Gaining knowledge and experience will make students more equipped when they start job hunting.

\section{METHODOLOGY}

This study employed the quantitative method of survey questionnaire to collect and analyze the data among practitioners of public relations in Malaysia. There are no comprehensive data on the number of public relations practitioners in Malaysia (Kaur, 2002; and Idid, 1992).

A total of 427 questionnaires were distributed to the respondents, and only 322 surveys were returned. Practitioners were identified through several ways such as websites, public and private sectors, IPRM, educational institutions, and public 
relations agencies. This study employed convenience sampling to gather data from the respondents on professional values; professionalism; and code of ethics.

\section{HYPOTHESES}

The study by Giannoni (2002) found that a higher education level has a positive influence on the level of professionalism in the New Jersey State Police. West \& Shanafelt (2007) said that medical education is enhancing the development of professionalism among its students. Hultman, Halvorson, Kaye, Helgans, Meyers, Rowland \& Meyer (2013) said that teaching of professionalism is considered very valuable and should be applied by educators, because it improves the performance of an organization and helps to maintain certification requirements. Based on the findings from previous studies, it is suggested that:

H1: There is a positive relationship between education and professionalism.

Elm, Kennedy \& Lawton (2001) found a positive relationship between moral reasoning and education level with graduate students having a higher level of moral reasoning than undergraduate students. The higher the level of education, the better the demonstration of moral reasoning by students. Yan (2012) said that ethics education is considered necessary for engineering education. Jazani \& Ayoobzadeh (2012) found that taking courses on ethics influences the adherence level of people in both personal and educational ethics. Based on what is mentioned above, it is suggested that:

H2: There is a positive relationship between education and code of ethics.

The findings of Kim \& Reber (2009) showed that practitioners who had long working experience in large public relations departments had a positive influence on professionalism. The study also found a positive significant correlation on both the length of practice and size of public relations department with the professionalism of practitioners. Fantahun, Demessie, Gebrekirstos, Zemene \& Yetayeh (2014) found a significant correlation between professionalism and both work experience and age of respondents. Wynd (2003) said that professionalism had a significant relationship with years of experience, membership in organizations, higher educational degrees, specialty certification, and service as an officer in the organization.

Macpherson (2012) mentioned that the experience and knowledge of scientists allow them to develop the objectives, topics, and goals related to the professionalism 
of their own courses and disciplines. Martin, Meyer, Jones, Nelson \& Ting (2010) stated that having more years of experience, higher level of education, and being older in age is associated with a greater perception on professionalism in childcare. Consequently, it is hypothesized that:

H3: Experience is positively related to professionalism.

Sharma (2009) found that working experience has a significant positive correlation with the ethical behavior of managerial personnel. Managers with long working experience are more ethical than those who have less working experience. Eweje \& Brunton (2010) suggested that working experience has an influence on the ethical judgment of respondents of their study. Respondents with more working experience are more ethically aware and demonstrate higher ethical judgments than those with less working experience.

Reiss \& Mitra (1998) mentioned that years of working experience and the area of study have an influence on the acceptability of particular workplace behaviors. Lv \& Huang (2012) said that the working environment and working experience have an influence on the moral judgment of individuals. John \& Wells (2013) found a relationship between professional commitment and both years of working experience and organization of employment. Consequently, it is hypothesized that:

H4: Experience is positively related to code of ethics.

In public relations both Boynton (2006) and Global Alliance for Public Relations and Communication Management (2010) considered professionalism as a professional value of public relations. The Global Alliance for Public Relations and Communication Management stated five professional values, of which professionalism is considered as one of them. The American Physical Therapy Association (2003) has identified the core professional values on professionalism which is used to define the important elements of professionalism in physical therapy. The study by Panina \& Bierman (2013) stated that the ideals of professionalism in Russia can be reflected by a new set of professional values which can legitimize the recently created formal legal institutions. There is a positive trend to develop legal professionalism in Russia although there is maybe some comparison in developing professional values through some informal practices from professional socialization agents. 
Salam, Song, Mazlan, Hassin, Lee \& Abdullah (2012) mentioned that there was a requirement for high standards of behavior with regards to the core values of professionalism in medicine. This requirement came out to cross study sections on core values of professionalism. Kasule (2013) stated that professionalism from an Islamic perspective should be based on basic values which consisted of faith, excellent character, and strive towards perfection, consciousness, responsibility, excellent performance, and self-accountability. Consequently, it is hypothesized that:

H5: The higher the perception on professionalism, the higher the perception on professional values.

Grunig (2000) mentioned that values in public relations is considered as the center of ethical decision-making. Grunig, Toth \& Hon (2000) believed that codes of ethical standards obtained by practitioners from actual situations were based on values. The teaching of values is a significant introduction to the teaching of ethics. Campbell \& Zegwaard (2011) stated that both ethics and values education have a role in changing and shaping the workplace of emerging professionals. The education of professional ethics should facilitate the exploration of both values and moral frameworks in students. Hartranft (2009) mentioned that ethical ideology had a significant influence on the measure of professional values. Consequently, it is hypothesized that:

H6: The higher the perception on code of ethics, the higher the perception on professional values.

\section{DEMOGRAPHIC CHARACTERISTICS}

There were 322 respondents. In terms of age, $47 \%$ of respondents were from 18-30 years, 32\% were from 31-40 years, $15 \%$ were from $41-50$ years, and those who were 51 years and above were $6 \%$. A total of $61 \%$ were female respondents, and $39 \%$ were male respondents. Public relations practitioners with a Bachelor degree were $48 \%$, followed by Diploma holders (20\%), and Postgraduate degree holders (21\%). There were $73 \%$ Malay, 12\% Chinese, and 7\% Indian respondents. Muslims made up 78\%, followed by Christians with $9 \%$. Buddhists with $9 \%$, Hindus with $3 \%$, and other religions with only $1 \%$.

Practitioners who earned between RM1000 and less figured 6\%; those from RM1001-2000 figured 16\%; those from RM2001-3000 figured 31\%; those from 
RM3001-4000 figured $19 \%$; those from RM4001-5000 figured 8\%; those from RM5001-6000 figured 5\%; those from RM6001-7000 figured 6\%, and those from RM7001 and above figured $10 \%$.

Table 1.1 Demographic Characteristics of Respondents.

\begin{tabular}{|c|c|c|}
\hline Items & $\mathbf{N}$ & Percentage \\
\hline \multicolumn{3}{|c|}{ Age } \\
\hline $18-30$ years & 150 & $47 \%$ \\
\hline $31-40$ years & 102 & $32 \%$ \\
\hline $41-50$ years & 48 & $15 \%$ \\
\hline 51 years and above & 20 & $6 \%$ \\
\hline Total & 320 & 100.0 \\
\hline \multicolumn{3}{|c|}{ Gender } \\
\hline Male & 120 & $39 \%$ \\
\hline Female & 184 & $61 \%$ \\
\hline Total & 304 & 100.0 \\
\hline \multicolumn{3}{|c|}{ Highest Education Obtained } \\
\hline SPM \& STPM & 35 & $11 \%$ \\
\hline Diploma & 63 & $20 \%$ \\
\hline Bachelor Degree & 153 & $48 \%$ \\
\hline Postgraduate & 67 & $21 \%$ \\
\hline Total & 318 & 100.0 \\
\hline \multicolumn{3}{|c|}{ Race } \\
\hline Malay & 234 & $73 \%$ \\
\hline Chinese & 37 & $12 \%$ \\
\hline Indian & 22 & $7 \%$ \\
\hline Bumiputera & 16 & $5 \%$ \\
\hline Others & 11 & $3 \%$ \\
\hline Total & 320 & 100.0 \\
\hline \multicolumn{3}{|c|}{ Religion } \\
\hline Islam & 249 & $78 \%$ \\
\hline Christianity & 30 & $9 \%$ \\
\hline Buddhism & 28 & $9 \%$ \\
\hline
\end{tabular}




\begin{tabular}{|c|c|c|}
\hline Hinduism & 9 & $3 \%$ \\
\hline Others & 4 & $1 \%$ \\
\hline Total & 320 & 100.0 \\
\hline \multicolumn{3}{|c|}{ Monthly Salary } \\
\hline RM1000 and less & 18 & $6 \%$ \\
\hline RM1001 - 2000 & 52 & $16 \%$ \\
\hline RM2001 - 3000 & 98 & $31 \%$ \\
\hline RM3001 - 4000 & 59 & $19 \%$ \\
\hline RM4001 -5000 & 24 & $8 \%$ \\
\hline RM5001 -6000 & 17 & $5 \%$ \\
\hline RM6001 -7000 & 19 & $6 \%$ \\
\hline RM7001 and above & 30 & $10 \%$ \\
\hline Total & 317 & 100.0 \\
\hline
\end{tabular}

\section{WORKPLACE PROFILE}

Table 1.2 shows that $77 \%$ of public relations practitioners were permanent in their place of work, whereas those on contract were $12 \%$; those with temporary status $7 \%$; and practitioners under probation were $4 \%$.

Public relations practitioners with 5 and less years of working experience comprised $71 \%$; those with 6 to 10 years of working constituted 14\%; those with 11 to 15 years of working experience figured 7\%; those with 16 to 20 years of working experience constituted $3 \%$; and those with 21 years and above of working experience figured $5 \%$.

On the other hand, the majority of organizations were local and constituted $90 \%$ while foreign organizations constituted $10 \%$.

Table 1.2 shows that the government sector made up $26 \%$, followed by corporation which figured 20\%; and other organizations were 19\%. Educational organizations comprised $10 \%$, followed by $5 \%$ of health and welfare, and trade and professional associations. $81 \%$ were non-accredited practitioners by IPRM, while $19 \%$ were accredited practitioners. The non-members of IPRM were $83 \%$, whereas $17 \%$ were members. 
The majority of respondents, who were not members in any professional association, was $93 \%$, while those who were members were only $7 \%$. Hence a majority of the respondents were not members of professional associations.

Table 1.2 Workplace Profile of Respondents.

\begin{tabular}{|c|c|c|}
\hline \multicolumn{3}{|c|}{ Work Status } \\
\hline Temporary & 23 & $7 \%$ \\
\hline Probation & 11 & $4 \%$ \\
\hline Permanent & 245 & $77 \%$ \\
\hline Contract & 39 & $12 \%$ \\
\hline Total & 322 & $\mathbf{1 0 0 . 0}$ \\
\hline \multicolumn{3}{|c|}{ Service as PR Practitioner } \\
\hline 5 years $\&$ less & 211 & $71 \%$ \\
\hline $6-10$ years & 41 & $14 \%$ \\
\hline 11-15 years & 21 & $7 \%$ \\
\hline $16-20$ years & 8 & $3 \%$ \\
\hline $21 \&$ above & 15 & $5 \%$ \\
\hline Total & 296 & 100.0 \\
\hline \multicolumn{3}{|c|}{ Status of Organization } \\
\hline Local & 233 & $90 \%$ \\
\hline Foreign & 27 & $10 \%$ \\
\hline Total & 260 & $\mathbf{1 0 0 . 0}$ \\
\hline \multicolumn{3}{|c|}{ Category of Organization } \\
\hline Agency & 44 & $15 \%$ \\
\hline Corporation & 58 & $20 \%$ \\
\hline Government Sector & 75 & $26 \%$ \\
\hline Health/Welfare & 15 & $5 \%$ \\
\hline Education & 30 & $10 \%$ \\
\hline Trade and Professional Association & 15 & $5 \%$ \\
\hline Other & 57 & $19 \%$ \\
\hline Total & 294 & 100.0 \\
\hline
\end{tabular}




\begin{tabular}{|l|c|c|}
\hline Yes & 57 & $19 \%$ \\
\hline No & 249 & $81 \%$ \\
\hline Total & $\mathbf{3 2 2}$ & $\mathbf{1 0 0 . 0} \%$ \\
\hline \multicolumn{3}{|c|}{ IPRM Membership } \\
\hline Yes & 49 & $17 \%$ \\
\hline No & 246 & $83 \%$ \\
\hline Total & $\mathbf{3 2 2}$ & $\mathbf{1 0 0 . 0}$ \\
\hline \multicolumn{3}{|c|}{ Membership of Professional Association } \\
\hline Yes & 22 & $7 \%$ \\
\hline No & 284 & $93 \%$ \\
\hline Total & $\mathbf{3 2 2}$ & $\mathbf{1 0 0 . 0}$ \\
\hline
\end{tabular}

\section{CONCEPTUAL FRAMEWORK}

The concern of this study is based on professional values in the workplace. Figure 1.1 shows the relationship between four independent variables (education, experience, professionalism, and code of ethics), and one dependent variable (professional values). This section develops the constructs of the research model and the hypothesized relationships examined among public relations practitioners. The model suggests professionalism and code of ethics play a central role in professional values. Further, it indicates that the professionalism and code of ethics are affected by education and experience.

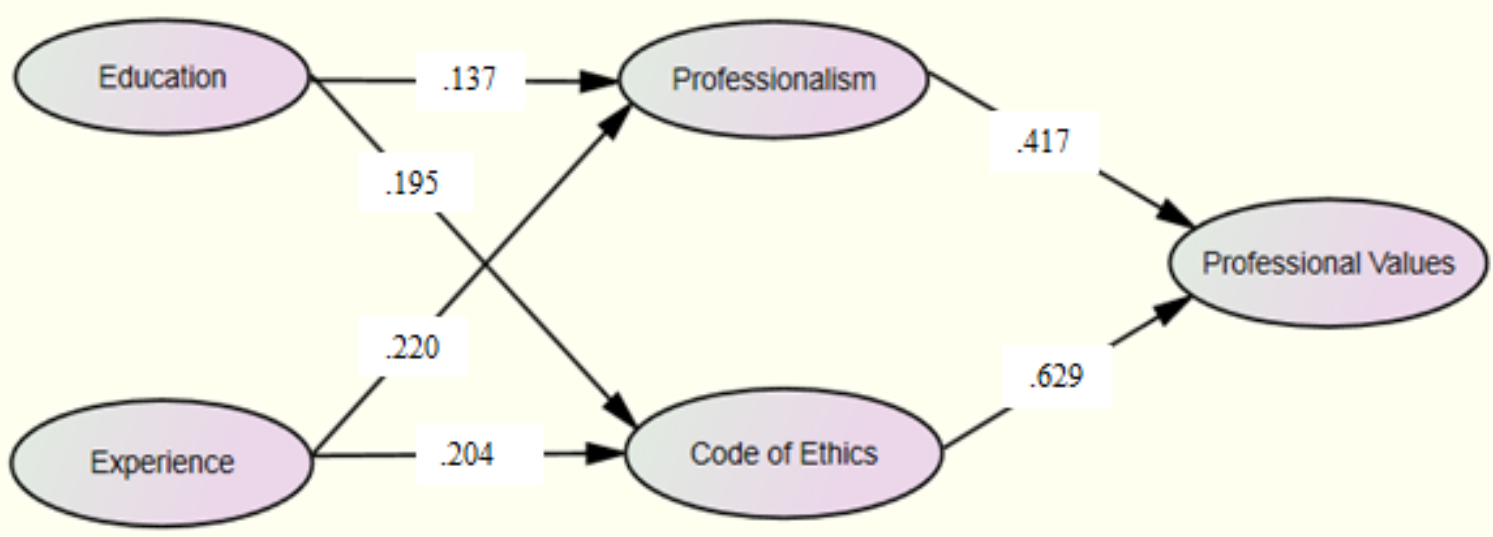


Figure1.1 Conceptual framework of the Relationship among Variables

This conceptual framework has been used to show the relationships of the concepts, and it has been constructed made to guide the study. This conceptual framework has indicated the relationships among concepts, and how the involved concepts have been viewed in the study. The construction of this conceptual framework and choosing the relationship between these variables is based on what was found in previous studies such as (Al-Enad, 1992; Rassin, 2008; Winston, 2005; Barnard, 2008; Boynton, 2006; \& Panina \& Bierman, 2013; and Synnott, 2001). These studies have provided strong evidence about the relationship among the variables in this conceptual framework.

Correlation analysis was applied to determine the relationship among variables in the conceptual model. In order to test the first hypothesis, a correlation analysis (Figure 1.1) was applied to determine the relationship between education and professionalism. The result showed a positive significant relationship between education and professionalism $(\mathrm{r}=.137 ; p=.015)$, which supports the first hypothesis

Correlation test was applied to assess the relationship of the second hypothesis between education and code of ethics. Figure 1.1 showed a positive significant relationship between education and code of ethics $(\mathrm{r}=.195 ; p=.001)$, which supports the second hypothesis (There is a positive relationship between education and code of ethics).

Regarding the third hypothesis, a correlation analysis was applied to assess the relationship between service as PR practitioners and professionalism. Figure 1.1 showed that there was a positive significant relationship between service as PR practitioners and professionalism $(\mathrm{r}=.220 ; p=.000)$, which supports the third hypothesis (Experience is positively related to professionalism).

The test for the fourth hypothesis applied correlation analysis (Figure 1.1) to assess the relationship between service as PR practitioners and code of ethics. The result showed a positive significant relationship between service as PR practitioners and code of ethics $(\mathrm{r}=.204 ; p=.000)$. This supports the fourth hypothesis (Experience is positively related to code of ethics).

The assessment of the relationship between professionalism and professional values in the fifth hypothesis has done through correlation analysis. In Figure 1.1, the correlation analysis showed a positive significant relationship between 
professionalism and professional values $(\mathrm{r}=.417 ; p=.000)$, thus supporting the fifth hypothesis (The higher the perception on professionalism, the higher the perception on professional values).

Finally, to test the sixth hypothesis, correlation analysis was applied to assess the relationship between code of ethics and professional values. Figure 1.1 showed a positive significant relationship between professionalism and professional values $(\mathrm{r}=$ $.629 ; p=.000$ ), which supports the sixth hypothesis (The higher the perception on code of ethics, the higher the perception on professional values).

\section{DISCUSSION \& CONCLUSION}

Five items were used in this study, namely education, length of service / experience, professionalism, code of ethics, to assess their influence on professional values. Six hypotheses were stated in this study, all of which were supported. The first hypothesis mentioned a positive relationship between education and the professionalism of public relations practitioners. The second hypothesis stated a positive significant relationship between education and code of ethics. The third hypothesis showed a positive significant relationship between service as PR practitioners and professionalism. The fourth hypothesis mentioned a positive significant relationship between service as PR practitioners and code of ethics. The fifth hypothesis showed a positive significant relationship between professionalism and professional values. The sixth hypothesis showed a positive significant relationship between code of ethics and professional values.

Education and length of service were factors that influenced professionalism and code of ethics. What the findings found was that practitioners with a high level of education and had been long in service found accepted professionalism in their practice and also were acceptable to be guided and governed by ethical conduct. Since a majority of them are members of professional associations it also meant that they accepted ethical practice in the conduct of their work.

Professional values are correlated with professionalism and code of ethics. It was from the literature that the study found ethics and professionalism to be integral to professional values. It is evident that practitioners who aim to have professional values in their practice must begin with accepting professionalism and the code of ethics. 
The topic of professional values is important and critical to public relations and its practitioners. The literature review reveals the relationship between professional values and the factors influencing it. It appears that professionalism, ethics, education, and experience have an influence on the professional values of public relations practitioners.

\section{LIMITATIONS}

Limitations of this research included the non-comprehensive list of public relations practitioners in Malaysia. The study also adopted convenience sample, which did not represent all public relations practitioners in Malaysia. The study also applied only a quantitative methodology. The number of practitioners that the study obtained was more than the number that was obtained by Idid in his previous studies, giving confidence that the findings could encompass the thinking of the practitioners.

\section{RECOMMENDATIONS}

It is recommended that future research should conduct a qualitative method besides the survey questionnaire. Using a qualitative method might be useful in giving participants a chance to obtain sufficient information and elaborate more on their perception regarding this topic. It is suggested that future research should apply probability sampling that allows generalizing of results in the future research.

\section{ABOUT THE AUTHORS}

Dr. Syed Arabi Idid is currently a Professor in the Department of Communication, Kulliyyah of Islamic Revealed Knowledge and Human Sciences, International Islamic University Malaysia (IIUM). He was Dean of the Research Centre in July 2001 and was later appointed as Rector of IIUM from $1^{\text {st }}$ June 2006 until $31^{\text {st }}$ May 2011. He was at the Universiti Kebangsaan Malaysia (UKM) for 22 years before joining IIUM in 1999.

Mohammed Arandas is a Ph.D. candidate at School of Media and Communication Studies, Faculty of Social Sciences and Humanities, The National University of Malaysia. He obtained his Master in Communication from the Department of Communication, International Islamic University Malaysia. He completed his Bachelor degree in Media/ Public Relations at Al-Aqsa University. 


\section{REFERENCES}

Abdullah, Z., \& Threadgold, T. (2008). Towards the professionalisation of public relations in Malaysia: Perception management and strategy development. Public Relations Review, 34 (3), 285-287.

Ahmad, J. H. (2010). Opportunities and challenges for public relations practitioners in Malaysia. CoverAge: Journal of Strategic Communication, 1 (1), 1-10.

Al-Enad, A. H. (1992). Values of public relations conduct in Saudi Arabia. Public Relations Review, 18 (2), 213-221.

Allen, J., \& Davis, D. (1993). Assessing some determinant effects of ethical consulting behavior: The case of personal and professional values. Journal of Business Ethics, 12 (6), 449-458.

American Physical Therapy Association. (2003). Professionalism in physical therapy: $\begin{array}{lllll}\text { core } & \text { values. } & \text { Retrieved } & \text { April }\end{array}$ http://www.apta.org/uploadedFiles/APTAorg/About_Us/Policies/BOD/Judicial /ProfessionalisminPT.pdf

Barnard, A. (2008). Values, ethics and professionalization a social work history. In Barnard, A., Horner, N., \& Jim, W (Eds.), The value base of social work and social care: An active learning handbook. Maidenhead, UK: Open University Press.

Boynton, L. A. (2006). What we value: A delphi study to identify key values that guide Ethical Decision-Making in Public Relations. Public Relations Review, 32 (4), 325-330.

Campbell, M., \& Zegwaard, K. E. (2011). Values, ethics and empowering the self through cooperative education. Asia-Pacific Journal of Cooperative Education, $12(3), 205-216$.

Elm, D. R., Kennedy, E. J., \& Lawton, L. (2001). Determinants of moral reasoning: Sex role orientation, gender, and academic factors. Business \& society, 40 (3), 241-265.

Evetts, J. (2003). The sociological analysis of professionalism: Occupational change in the modern world. International Sociology, 18 (2), 395-415. 
Eweje, G., \& Brunton, M. (2010). Ethical perceptions of business students in a New Zealand university: do gender, age and work experience matter? Business Ethics: A European Review, 19 (1), 95-111.

Fantahun, A., Demessie, A., Gebrekirstos, K., Zemene, A., \& Yetayeh, G. (2014). A cross sectional study on factors influencing professionalism in nursing among nurses in Mekelle Public Hospitals, North Ethiopia, 2012. BMC nursing, 13 (10), 1-7.

Freidson, E. (1994). Professionalism reborn: theory, prophecy, and policy. Chicago: The University of Chicago Press.

Freitag, A. \& Stokes, A. (2009). Global public relations: Spanning borders, spanning cultures. Abingdon, UK: Routledge.

Giannoni, M. A. (2002). An ethnographic investigation of police education: Implications for professionalism and continuing criminal justice education. Ph.D. Dissertation, Northern Illinois University, ProQuest Dissertations and Theses.

Global alliance for public relations and communication management. (2010). Vision, Mission \& Values. Retrieved March 15, 2013. http://www.globalalliancepr.org/website/page/vision-mission-values

Grunig, L. A., Toth, E. L., \& Hon, L. C. (2000). Feminist values in public relations. Journal of Public Relations Research, 12 (1), 49-68.

Grunig, J. E. (2000). Collectivism, collaboration, and societal corporatism as core professional values in public relations. Journal of Public Relations Research, 12 (1), 23-48.

Hartranft, S. R. (2009). The effect of ethical ideology and professional values on registered nurses' intentions to act accountably. Ph.D. Dissertation, University of South Florida. ProQuest Dissertations and Theses.

Hultman, C. S., Halvorson, E. G., Kaye, D., Helgans, R., Meyers, M. O., Rowland, P. A., \& Meyer, A. A. (2013). Sometimes you can't make it on your own: the impact of a professionalism curriculum on the attitudes, knowledge, and behaviors of an academic plastic surgery practice. Journal of Surgical Research, 180 (1), 8-14.

Idid, S.A. (1986). Perhubungan Awam di Malaysia. Satu Tinjauan. Mimeograf, Jabatan Komunikasi, Bangi: Universiti Kebangsaan Malaysia. 
Idid, S. A. (1992) Specifying a target population: the case of the Malaysian public relations practitioners. Jurnal Komunikasi; Malaysian Journal of Communication, 8, 131-140.

Idid, S. A. (1998). Beauty, brain and brawn in public relations. Bangi, Selangor: Universiti Kebangsaan Malaysia.

Idid, S. A. (2005). Institute of public relations in malaysia: A historical perspective. Research Centre, International Islamic University Malaysia.

Institute of Public Relations Malaysia. (2012). IPRM accreditation programme. $\begin{array}{lll}\text { Retrieved } & \text { February } & 2014 .\end{array}$ http://iprm.org.my/download/accreditationprogramme-2011.pdf

Jazani, N., \& Ayoobzadeh, M. (2012). The impact of ethics training course on ehical behaviors of management students. International Business Research, 5 (11), $162-168$

John, W., \& Wells, Jr. (2013). Commitment, ethics \& compliance a look at perception in the SH \& E profession. Professional Safety Journal of the American Society of Safety Engineers, Sep, 62-68.

Kasule, O. H. (2013). Medical professionalism and professional organizations. Journal of Taibah University Medical Sciences, 8 (3), 137-141.

Kaur, K. (2002). Public relations professionalism in Malaysia. The $52^{\text {nd }}$ International Communication Association Conference. Seoul, South Korea, pp. 155 -173.

Kaur, K., \& Shaari, H. (2006). Perception on the relationships between public relations practitioners and journalists. Kajian Malaysia, 24, (1/2), 9- 32.

Kim, S. Y., \& Reber, B. H. (2009). How public relations professionalism influences corporate social responsibility: A survey of practitioners. Journalism \& Mass Communication Quarterly, 86 (1), 157-174.

Kruckeberg, D. (1998). The future of pr education: Some recommendations. Public Relations Review, 24 (2), 235-248.

Kubsch, S., Hansen, G., \& Huyser-eatwell, V. (2008). Professional values: The case for RN- BSN completion education. The Journal of Continuing Education in Nursing, 39 (8), 375- 384. 
Leners, D. W., Roehrs, C., \& Piccone, A. V. (2006). Tracking the development of professional values in undergraduate nursing students. Journal of Nursing Education, 45 (12), 504-511.

Lv, W., \& Huang, Y. (2012). How workplace accounting experience and gender affect ethical judgment. Social Behavior \& Personality: An International Journal, 40 (9), 1477-1484.

MacCarthaigh, M. (2008). CPMR discussion Paper39: public service values. Dublin: Institute of Public Administration. Retrieved February 24, 2013. http://www.emeraldinsight.com

Macpherson, C. C. (2012). Teaching professionalism in science courses: Anatomy to zoology. The Kaohsiung journal of medical sciences, 28 (2), S8-S12.

Martin, S., Meyer, J., Jones, R. C., Nelson, L., \& Ting, L. (2010). Perceptions of professionalism among individuals in the child care field. Child \& Youth Care Forum, 39 (5), 341-349.

Panina, D., \& Bierman, L. (2013). The development of legal professionalism in Russia: an institutional perspective. Critical Perspectives on International Business, 9 (1), 106-128.

Parsons, P.J. (2008). Ethics in public relations: A guide to best practice ( $2^{\text {nd }}$ edn). London and Philadelphia: Kogan Page.

Public Relations Society of America. (2000). PRSA Member Code of Ethics. Retrieved March 2, 2013. http://www.prsa.org/aboutprsa/ethics/codeenglish/

Rassin, M. (2008). Nurses professional and personal values. Nursing Ethics, 15(5), 614-630.

Reiss, M. C., \& Mitra, K. (1998). The effects of individual difference factors on the acceptability of ethical and unethical workplace behaviors. Journal of Business Ethics, 17 (14), 1581-1593.

Salam, A., Song, C. O., Mazlan, N. F., Hassin, H., Lee, L. S., \& Abdullah, M. H. (2012). A pilot study on professionalism of future medical professionals in Universiti Kebangsaan Malaysia (UKM) Medical Centre. Procedia - Social and Behavioral Sciences, 60 (17 Oct), 534-540.

Schank, M. J., \& Weis, D. (2001). Service and education share responsibility for nurses' value development. Journal for Nurses in Staff Development, 17 (5), 226-231. 
Sha, B. L. (2011). Accredited vs. non-accredited: The polarization of practitioners in the public relations profession. Public Relations Review, 37 (2), 121-128.

Sharma, S. (2009). Role of age and work experience in ethical behavior. The IUP Journal of Organizational Behaviour. April (09), 35-41.

Singhapakdi, A., \& Vitell, S. J. (1993). Personal and professional values underlying the ethical judgments of marketers. Journal of Business Ethics, 12 (7), 525533.

Synnott, G. (2001). Values and identity in public relations practice in Malaysia. Unpublished Ph.D. Dissertation, Murdoch University.

Taylor, M., \& Kent, M. L. (1999). Challenging assumptions of international public relations: When government is the most important public. Public Relations Review, 25 (2), 131-144.

Turk, J. V. (2006). The professional bond: Public relations education and the practice. Virginia: The Commission on Public Relations Education.

West, C. P., \& Shanafelt, T. D. (2007). The influence of personal and environmental factors on professionalism in medical education. BMC medical education, 7 (29), 1-9.

Wilcox, D., \& Cameron, G. T. (2009). Public relations strategies and tactics (9th edn.). Boston: Pearson.

Winston, M. (2005). Ethical leadership: Professional challenges and the role of LIS education. New Library World, 106 (5/6), 234-243.

Wong, A., M.D. (2011). From the front lines: A qualitative study of anesthesiologists' work and professional values. Canadian Journal of Anesthesia, 58 (1), 108-17.

Wylie, W. F. (1994). Commentary: Public relations is not yet a profession. Public Relations Review, 20 (1), 1-3.

Wynd, C. A. (2003). Current factors contributing to professionalism in nursing. Journal of Professional Nursing, 19 (5), 251-261.

Yan, H. (2012). Keystone of engineering education - ethics education. In Liangchi, Z., \& Chunliang, Z (Eds.), Engineering education and management (pp. 493497). Berlin: Springer Berlin Heidelberg. 